\title{
Polens syn på NATO, EU og Rusland
}

\section{Radoslaw Sikorski}

\section{Ifølge Polens udenrigsminister er en af de vigtig- ste udenrigspolitiske opgaver at sikre balancen mellem de europæiske og de transatlantiske sik- kerhedsdimensioner}

Lad mig starte med ganske kort at skildre de omvæltninger i Polens nyere historie, som uden tvivl er med til at forme vore udenrigspolitiske standpunkter.

Efter Anden Verdenskrig var Den Polske Folkerepublik en stat med begrænset suverænitet, indlemmet i et system af satellitstater skabt af Sovjetunionen. Dette system var et resultat af Jaltakonferencens beslutning om at inddele Europa i indflydelsessfærer. Vort land har altid betragtet sig som en del af den vestlige civilisation, alligevel strandede Polen og andre lande i regionen på grund af Jalta uden for den.

I dag er der en tilbøjelighed til, at den fremtrædende Solidaritetsbevægelse og dens bedrifter i kampen mod kommunismen overskygges af Berlinmurens spektakulære fald i november 1989. Men uden Solidari- tets standhaftige kamp, ledet af nobelprisvinderen Lech Walesa, ville Muren formentlig først være faldet langt senere, måske engang i løbet af næste generation.

Solidaritet demonstrerede at kommunismen kunne besejres. Og endnu vigtigere, den fredelige Solidaritetsrevolution er stadig en gyldig model for, hvordan man vælter et tyrannisk styre uden at gribe til vold.

\section{Polens plads i Europa}

Efter at have genvundet sin uafhængighed i 1989 stod Polen over for den vigtige opgave at genopbygge sin økonomi og transformere sit politiske system. Landets udenrigspolitik skulle omlægges radikalt og tilpasses de ændrede internationale vilkår. Solidaritetsaktivisterne der havde overtaget magten, havde ikke 
haft mulighed for at udforme et sammenhængende udenrigspolitisk program. Det måtte skabes i farten, og Polen skulle handle hurtigt for at definere sin plads i Europa:

- Hvordan skulle Polens sikkerhed garanteres i dets særlige geopolitiske omgivelser?

- Hvordan skulle det nærme sig europæisk integration?

- Hvilke relationer skulle det have til Sovjetunionen og de stadig mere uafhængigt-sindede sovjetrepublikker?

- Og endelig, hvilket forhold skulle Polen søge at få til USA - vinderen af den kolde krig og den eneste tilbageværende supermagt?

Svaret var utvetydigt: Polen skulle have tætte forbindelser til Europa og blive et fuldgyldigt medlem af den Europæiske Union, som rummede den optimale formel for kontinentets politiske og økonomiske enhed. EU der repræsenterede værdier, som Polen delte, ville styrke vort demokrati og give os et klart udviklingsperspektiv.

\section{NATO}

Indtil 1991 var Polen medlem af Warszawapagten, og sovjetiske tropper var stationeret $\mathrm{i}$ vort land indtil 1993. Ikke desto mindre mente nogle politikere, inklusive mig selv, allerede i begyndelsen af 1990 'erne, at NATO bedst kunne garantere Polens uafhængighed og sikkerhed. Jeg var personligt overbevist om, at det ville være nemmere og hurtigere at udvide NATO end at optage nye medlemmer i EU.

Vor største bekymring var, hvordan vi skulle forhindre, at Polen pludselig befandt sig i en sikkerhedspolitisk gråzone uden klare garantier fra USA og dets europæiske partnere, og - sammen med andre stater i regionen - blev betragtet som stødpude mellem Vesten og Rusland.

Udvidelsen af NATO - i første omgang med optagelsen af de centraleuropæiske lande, der havde frigjort sig fra sovjetisk dominans - var et politisk dristigt træk. Det garanterede Polen og dets naboer deres sikkerhed, forkastede arven fra Jalta og styrkede betragteligt den europæiske søjle i NATO. På en måde bidrog NATO til at gøre EU's udvidelse nemmere og styrkede samtidig kontinentets enhed.

Det er ikke tilfældigt, at de nye stater i Alliancen er blandt dens mest aktive og pligttro medlemmer. Det samme gælder de nye stater i EU, hvoraf mange er gengangere: De er førende i den Europæiske Union hvad angår økonomisk vækst, og de har tilført det indre marked talrige, stadigt mere velhavende, forbrugere og dermed fremmet den økonomiske udvikling i hele Europa.

NATO er den primære institution med hensyn til at garantere Polens sikkerhed. Den skal forblive et instrument for kollektivt forsvar og 
det vigtigste forum for transatlantiske sikkerhedskonsultationer, uanset at der er en stigende sandsynlighed for, at NATO oftere vil engagere sig uden for traktatområdet.

\section{USA}

Der er ikke nogen modsætning mellem på den ene side et aktivt engagement i den europæiske integrationsproces og på den anden side indsatsen i NATO og udviklingen af tætte bånd til den amerikanske partner. Og det har der aldrig været. Det er en polsk udenrigspolitisk prioritet at sikre en balance mellem de europæiske og de transatlantiske sikkerhedsdimensioner.

For Polen, der er medlem af både EU og NATO, har det strategisk betydning, at der eksisterer et stærkt og effektivt atlantisk samarbejde, og erfaringer fra mange europæiske lande beviser gyldigheden af det polske standpunkt. Alliancen, som har ført Europa og USA sammen, baserer sig på fælles værdier, på forsvaret af demokrati, frihed og menneskerettigheder.

Køen af lande, der utålmodigt venter på at blive medlem af NATO, viser at denne særlige model for sikkerhed og disse særlige værdier har bibeholdt deres tiltrækningskraft og udgør et positivt referencepunkt i nutidens komplicerede internationale relationer.

Polen er på en og samme tid en loyal allieret til USA og en loyal partner i Europa, forpligtet over for den gryende fælles udenrigspolitik i EU. På samme tid forbliver NATO, hvor USA spiller en fremtrædende rolle, de næste mange år et bolværk for europæisk sikkerhed.

Derfor ønsker vi at NATO forbliver, hvad det altid har været: ikke kun en alliance, men også en militær organisation. NATO bygger sin troværdighed på uomtvistelige sikkerhedsgarantier, baseret på Washington-traktatens artikel fem og Alliancens militære organisation.

De hære og stater der er knyttet sammen inden for NATO, har haft tillid til, at der ikke kunne tilstøde dem noget ondt, fordi deres væbnede styrker var integrerede, og fordi garantierne ville blive opfyldt af de politiske beslutningstagere og NATO-styrkerne.

\section{Ukraine og Georgien}

På NATO-topmødet i Budapest i begyndelsen af april i år var Polen en af de mest energiske fortalere for at give Ukraine og Georgien en såkaldt Membership Action Plan. Vi mener at det at efterlade Ukraine og Georgien i en gråzone mellem Rusland og Europa kan friste til at genopbygge imperiet, som Zbigniew Brzezinski engang udtrykte det.

Derfor havde Robert Kagan ret, da han for nylig under en debat $i$ Warszawa gav udtryk for, at den bedste måde at sikre stabiliteten i Europas periferi var at fjerne denne re- 
gion fra det geopolitiske skakbræt ved at optage Ukraine og Georgien i NATO. At opretholde den åbne dørs politik styrker Alliancen og sikrer regional stabilitet. Den åbne dørs politik skal også gælde andre europæiske stater, herunder Finland.

\section{Den Europæiske Union}

Polen ønsker en energisk, stærk og sammenhængende Europæisk Union, der effektivt vil føre medlemsstaternes mål ud i livet inden for rammerne af den Fælles Udenrigs- og Sikkerhedspolitik (FUSP). Efterhånden som FUSP udvikler sig, håber vi at se en bedre koordination af EU's eksterne relationer.

I samme ånd ser vi frem til udviklingen af den Europæiske Sikkerheds- og Forsvarspolitik (ESDP), samtidig med at det strategiske partnerskab med NATO bibeholdes. Lissabon-traktatens ikrafttræden vil styrke EU og føre til en bredere, mere effektiv dialog med USA.

Vi tillægger også de nye samarbejdsperspektiver, som traktaten har skabt, stor betydning, især hvad angår EU's øgede evne til at handle og intervenere uden for egne grænser. Den evne bliver sat på prøve under den europæiske mission i Kosovo, hvor den skal operere side om side med KFOR, og under den fredsbevarende operation i Chad, hvor også Polen deltager.

I dag er EU uden tvivl det vigtigste referencepunkt i polsk udenrigspolitik. Polen er helt bevidst om betydningen af EU-medlemskabet og de politiske og økonomiske fordele, der er forbundet hermed.

Vi ønsker at den europæiske model for integration og fredeligt samarbejde skal udbredes uden for EU og blive en model for de ny demokratier. Derfor må vi ikke begrænse vort samarbejde med lande som Ukraine og Georgien. Deres politiske og økonomiske succes, stimuleret af den Europæiske Union, vil sætte et positivt eksempel for dem, der stadig vakler mellem demokrati og diktatur.

\section{Rusland}

EU's og NATOs vigtigste partner i Europa er Rusland. Som alle ved, har det polsk-russiske forhold en lang og stormfuld historie, som har set såvel krig, undertvingelse og nederlag som sejr og fredeligt samarbejde. Der er plads her til gensidig kulturel påvirkning og frugtbart $\varnothing$ konomisk samarbejde. Polen har en vital interesse i at udvikle gode naboforbindelser til Rusland. De er blevet bedre siden det seneste parlamentsvalg i Polen, som det fremgår af stigningen i bilaterale kontakter og resultaterne af premierminister Donald Tusks nylige besøg i Moskva. Vi håber, at de positive signaler bliver fuldt op af konkret handling fra russisk side.

Vi er særdeles interesserede i ud- 
viklingen af EU's samarbejde med Rusland, selv om vi føler at den russiske holdning over for EU ikke er entydig. På den ene side ser Kreml EU som en potentiel modvægt til amerikansk dominans, på den anden side frygter de fremkomsten af en alt for magtfuld Europæisk Union og en europæisk orden, hvor Rusland er marginaliseret.

Derfor tillægger Kreml forbindelserne til nøglelande som Tyskland, Frankrig, Storbritannien og Italien stor betydning. Det skal indrømmes, at Moskva er dygtig til at udnytte forskelligheden i interesser inden for EU og forhindre en koordinering af Unionens Øst-politik. Desuden er det vigtigt for Rusland at få adgang til de europæiske markeder, tiltrække investeringer fra EU og få finansiel og teknologisk støtte fra EU og de respektive medlemslande til dets moderniseringsprojekt.

De russiske myndigheders beslutninger om at bygge gasrørledninger til Vesteuropa uden om Centraleuropa, samtidig med at de forsøger at få kontrol over transportinfrastrukturen, har alvorlige politiske og $ø$ konomiske implikationer. Det afslører en stræben efter at skaffe sig redskaber til direkte indflydelse på de øst- og centraleuropæiske lande og andre EU-lande.

EU er nødt til at vie forholdet til Rusland særlig opmærksomhed. EU's medlemsstater og Rusland forfægter forskellige værdier, og det påvirker deres bilaterale forbindelser.
Jeg benægter ikke vor kritiske indstilling til visse dele af Ruslands indenrigspolitik. Desværre er begrebet 'fælles værdier' i forhold til Rusland gradvist - og med nogle medlemsstaters samtykke - ved at blive erstattet af fælles og, ind imellem, særlige interesser. Det fører til et farligt misforhold mellem praktiske handlinger og erklærede principper som i tilfældet med Ruslands overholdelse af menneskerettighederne eller dets ratifikation af Det Europæiske Energicharter.

\section{Behov for solidaritet}

Det betyder ikke at Polen er modstander af EU's samarbejde med Rusland. Vi føler tværtimod at et sådant samarbejde er afgørende for Europas trivsel og stabilitet, men det kan ikke ske samtidig med, at Rusland forsøger at splitte medlemsstaterne og behandle nogle bedre end andre. I forholdet til Rusland skal EU-landene udvise urokkelig indbyrdes solidaritet. Hvis den fastholdes, kan vi forvente at EU's politik over for Rusland vil give fordelagtige resultater.

Lad mig fx nævne Ruslands embargo mod polsk eksport af kød, som blev indført ene og alene af politiske grunde. Embargoen blev hævet - i høj grad takket være EU's solidaritet og støtte til Polen i samtalerne med Rusland. Som følge heraf har vi kunnet trække vore indvendinger mod forhandlingsmandatet 
om den nye samarbejdsaftale med Rusland tilbage.

Desværre mangler den solidaritet i energisamarbejdet med Rusland, og det udnytter Moskva til at fremme løsninger, der splitter medlemsstaterne og undergraver deres energisikkerhed. Nord Stream-projektet er et sigende eksempel: det er ikke $ø$ konomisk levedygtigt, det udgør en alvorlig miljøtrussel mod hele Østersøområdet, og det bruges til at inddele EU i gamle og ny medlemslande - dvs. lande som Moskva betragter som bedre eller dårligere samarbejdspartnere. De lande som for nylig befriede sig selv fra den østlige nabos dominans, har ret til at forvente, at deres allierede udviser større forståelse for deres bekymringer og interesser.

\section{Østersøområdet}

EU står over for en anden udfordring: at udvikle Østersøområdet til et kraftcenter for økonomisk vækst og innovation for hele kontinentet. Så sent som for 20 år siden var Østersøen stadig delt af Jerntæppet, og polske tropper blev trænet til en fremtidig landgang på danske kyster. I dag er de baltiske lande blandt de førende i EU hvad angår vækstrater, konkurrencedygtighed og innovation. Ved fælles anstrengelser kan vi nå endnu mere.

Men Østersøen er også et vigtigt område for samarbejde med Rusland, og vi håber at EU's fremtidige strategi for Østersøen aktivt vil tilskynde det.

EU har brug for en vidtfavnende og sammenhængende politik over for dens østlige naboer på det tidligere Sovjetunionens område - en politik af den type som vi tilstræber i forhold til vore middelhavspartnere. Forskellige initiativer er blevet søsat, fx partnerskabs- og samarbejdsaftaler, Den Nordlige Dimension, Det Europæiske Naboskabsprogram, Sortehavssynergi-initiativet og Det $\varnothing$ konomiske Samarbejde i Sortehavsområdet.

Vi mangler imidlertid en helt overordnet politisk plan, der tager højde for de pågældende landes forskellighed og etablerer en institutionel ramme for multilaterale forbindelser, der kunne være EU's Østlige Dimension. Den Østlige Dimension skal hvile på den grundlæggende forudsætning, at EU fører en sammenhængende politik over for hele det postsovjetiske område, en politik der er baseret på ens behandling af alle partnere uden hensyn til karakteren af deres forbindelse til EU, men som tager hensyn til deres forskellighed.

Ingen af staterne skal have lov til at skabe sig en dominerende position, da det vil være i strid med både EU's og dens østlige naboers interesser.

\section{Konklusion}

Jeg har i det foregående søgt at skit- 


\section{RADOSLAW SIKORSKI}

sere nogle vigtige elementer i Polens politik over for NATO, EU og Rusland. Vi erkender, at der inden for denne trekant er uoverensstemmelser om interesser og mål. Men det er helt naturligt - det er en væsentlig del af alle menneskers og staters handlinger. På den anden side deler EU og NATO en lang række fælles værdier, der retfærdiggør deres indbyrdes tætte bånd.

Vi ser optimistisk på den uenighed der eksisterer, da vi har lagt mærke til, at alle involverede parter er åbne for at tale sammen og nå til enighed. Det er i USA's, Ruslands og EU's bedste interesse at arbejde for positive, pragmatiske forbindelser på det politiske, økonomiske og sikkerhedsmæssige område - og det er helt afgørende for den globale stabilitet i disse flygtige og uforudsigelige tider.

Artiklen er en lettere bearbejdet udgave af en tale som Polens udenrigsminister, Radoslaw Sikorski, holdt i Det Udenrigspolitiske Selskab den 8. maj 2008.

Oversat fra engelsk af Brita $V$. Andersen 